\title{
A New Approach to Modeling Water Balance in Nile River Basin, Africa
}

\author{
Marye Belete ${ }^{1,2}$, Jinsong Deng ${ }^{1,3, *}$, Mengmeng Zhou ${ }^{1}$, Ke Wang ${ }^{1}$, Shixue You ${ }^{1}$, Yang Hong ${ }^{3,4}$ \\ and Melanie Weston ${ }^{1}$ \\ 1 College of Environmental and Resource Sciences, Zhejiang University, Hangzhou 310058, China; \\ marye_belete@zju.edu.cn (M.B.); mmzhou@zju.edu.cn (M.Z.); kwang@zju.edu.cn (K.W.); \\ 21614147@zju.edu.cn (S.Y.); 11614071@zju.edu.cn (M.W.) \\ 2 Agriculture and Environmental Sciences Faculty, Debre Tabor University, Debre Tabor 272, Ethiopia \\ 3 School of Civil Engineering and Environmental Sciences and School of Meteorology, \\ University of Oklahoma, Norman, OK 73019, USA; yanghong@ou.edu \\ 4 State Key Laboratory of Hydro Science and Engineering, Department of Hydraulic Engineering, \\ Tsinghua University, Beijing 100084, China \\ * Correspondence: jsong_deng@zju.edu.cn; Tel.: +86-571-8898-2623
}

Received: 23 January 2018; Accepted: 6 March 2018; Published: 14 March 2018

\begin{abstract}
The demand for calculating and mapping water yield is increasing for inaccessible locations or areas of conflict to support decision makers. Integrated Valuation of Environmental Services and Tradeoffs (InVEST) was applied to simulate basin hydrology. InVEST is becoming popular in the water modeling community due to its low requirements for input information, level of skill and model setup is available to the public domain. Estimation and mapping of water production, evapotranspiration and precipitation of the Nile River Basin have been performed by using open access data. This study utilized climate, soil and land use related data to model the key components of the water balance in the study region. Maps of the key parts of water balance were also produced. The spatial patterns of precipitation, actual evapotranspiration and water yield show sharp decline from south to northern part of the study basin while actual evapotranspiration fraction happens to the opposite. Our analysis confirms the ability of the InVEST water yield model to estimate water production capacity of a different part of a basin without flow meters.
\end{abstract}

Keywords: Nile Basin; water yield; spatial variation; InVEST; open access data

\section{Introduction}

According to Haines-young and Potschin [1], (p. 1), "no matter who we are, or where we live, our well-being depends on the way ecosystems work" because ecosystems are sources of basic needs that we depend on for our basic necessities, such as wood, food, clothes, shelter and medicines. Ecosystems also regulate the environment we live in through water and nutrient cycles, protect us from natural hazards like soil erosion and tsunamis; and they have spiritual and recreational values, but these benefits we get from ecosystems are simply overlooked. Recently, ecosystem services modeling is centered on water because fresh water is indispensable for food production, industrialization, domestic use, hydropower, fisheries, recreation and the entire natural functioning of ecosystems [2]. However, fresh water production is affected by population growth, land use, land cover change and climate change. For example, fresh water is becoming a source of conflict between riparian countries due to scarcity of fresh water availability in the Nile River Basin. To make the right decision and manage water resources properly, spatial and temporal information of the different components of freshwater availability is required $[3,4]$, but there is a lack of adequate information to support decisions in sub-Saharan Africa [5]. 
Efforts have been made to develop hydrological models by national and transnational organizations to encourage transboundary water collaboration and administration. For instance, the Georgia Institute of Technology developed the Nile Basin Decision Support Tool (DST) under the FAO-Nile project [6] for the Nile Basin Initiative (NBI), but the model setup is not reachable by practitioners and researchers. Maryland University has also developed NileSim water simulation model for the whole Nile Basin to be used by non-technical people. The model was intended to be freely accessible from the web, but it is no longer available [7].

In order to overcome model input data scarcity, newly developed models used remotely sensed data as inputs in the study area. For example, Mohamed et al. [8] developed a model over the whole Nile River Basin watershed. Senay et al. [9] also modeled the water balance dynamics of the whole Nile River Basin. For the period 1951-2000, Kirby et al. [10] developed a simple water model of the Nile River Basin. Africa-wide runoff distribution estimation was conducted by Senay and Verdin [11] at different watershed levels. More recently, Bastiaanssen et al. [12] modeled the water balance property of the whole Nile and its watersheds using remote sensing data for the first time. However, evapotranspiration data, an important part of the hydrological system, is not currently available. Even though the findings of the aforementioned researches are undoubtedly important, Johnston and Smakhtin [13] point out that they are neither published nor accessible. In addition, the findings of modeling may be accessible, whereas model setup is not reachable due to political reason in trans-boundary basins like the Nile River. Furthermore, Schuol et al. [14] modeled water yield, actual evapotranspiration, and soil water of the entire African continent at sub basin resolution by applying the Soil and Water Assessment Tool (SWAT) (USDA-ARS, Washington, DC, USA and Texas A\&M AgriLife Research, Dalas, TX, USA). Although SWAT is standard, publicly available and extensively applied for the sub basins of Nile River, in their review of 22 SWAT models, nine of which were water balance, Van Griensven et al. [15] discovered a lack of validation of the result and model calibration as well as unusual results of different studies on the same or similar catchments.

Although comparisons of the basin-wide models were rare, the results of simple water balance models are comparable with complex models $[16,17]$. Therefore, introducing a model requires low input data and level of skills, and utilizing open access data and the actual model setup in the public domain has paramount importance. Integrated Valuation of Environmental Services and Tradeoffs (InVEST) (The Natural Capital Project) annual water yield model has been developed according to these points of view [18].

InVEST is a collection of open-access and freely available software models applied to map and value ecosystem services from nature for sustaining normal ecosystems' functioning. Currently, InVEST consisted 18 different ecosystem service models for terrestrial, freshwater, marine, and coastal ecosystems. In addition, it has many "helper tools" to assist input data processing and visualizing model output. It can function in the ArcGIS Arc Toolbox environment or independently. We selected the InVEST annual water yield among the eighteen models. This model used simple production function compared with other processed-based hydrological models. The main strengths of the model are its low input data requirements, ease of use and model calibration being simple and objective. The model has acknowledged limitations. It neglects surface and base flow partitioning and inter-annual water delivery timing (see [18], for details).

This study aims to introduce the InVEST water yield model and demonstrate its applicability in the Nile River Basin to calculate and map water production. The model introduced here is an attempt to calculate and map spatial distribution of water production for the Nile River Basin and its sub-basins system delineated by NBI in 2016 using open access and globally available data. In the first part of the paper, we review previous studies about the hydrology of the Nile River Basin and the purpose of this study. The next parts deal with the physical characteristics of the Nile River Basin and methodology. Then, model results are described. This paper ends with a discussion and conclusion of the model's performance and its applicability in the Nile River Basin using open access data. 


\section{Materials and Methods}

\subsection{Study Area Description}

According to NBI [19], the Nile is $6695 \mathrm{~km}$ long and drains over 3,176,541 $\mathrm{km}^{2}$, which makes it the longest river on the planet earth and covers almost $10 \%$ of the African mainland. The Nile River flows through 11 countries of northeast Africa including Ethiopia, Tanzania, Sudan, Egypt, Kenya and has 10 sub-basins (see Figure 1). The main tributaries of Nile River are the White Nile with its upstream catchments fed by rivers originating in Burundi and in Rwanda and the Blue Nile originating in Ethiopia. Sobat River, Atbara River and Bahr el Ghazal are also contributing significant amounts of water for the Nile River. The Nile River flow shows the highest level of variability both in time and space compared with World's main river basin. The contribution of Ethiopian highlands is nearly $80 \%$ of the total flow in Egypt, whereas the lower Nile contributes a negligible amount [13].

The Nile River Basin is inhabited by 257 million people, which is more than half of riparian countries' total residence. A significant portion of the Nile Basin are arid and semi-arid ecosystems that determine the distribution of the population within the basin. Livelihoods of the riparian communities are entirely dependent on water resources of the Nile. Sustainable management of the shared waters is challenged by uneven distribution of the water between the riparian countries, population pressure, urbanization, scarcity of hydrological data, complex hydrology of the Nile system and climate change.

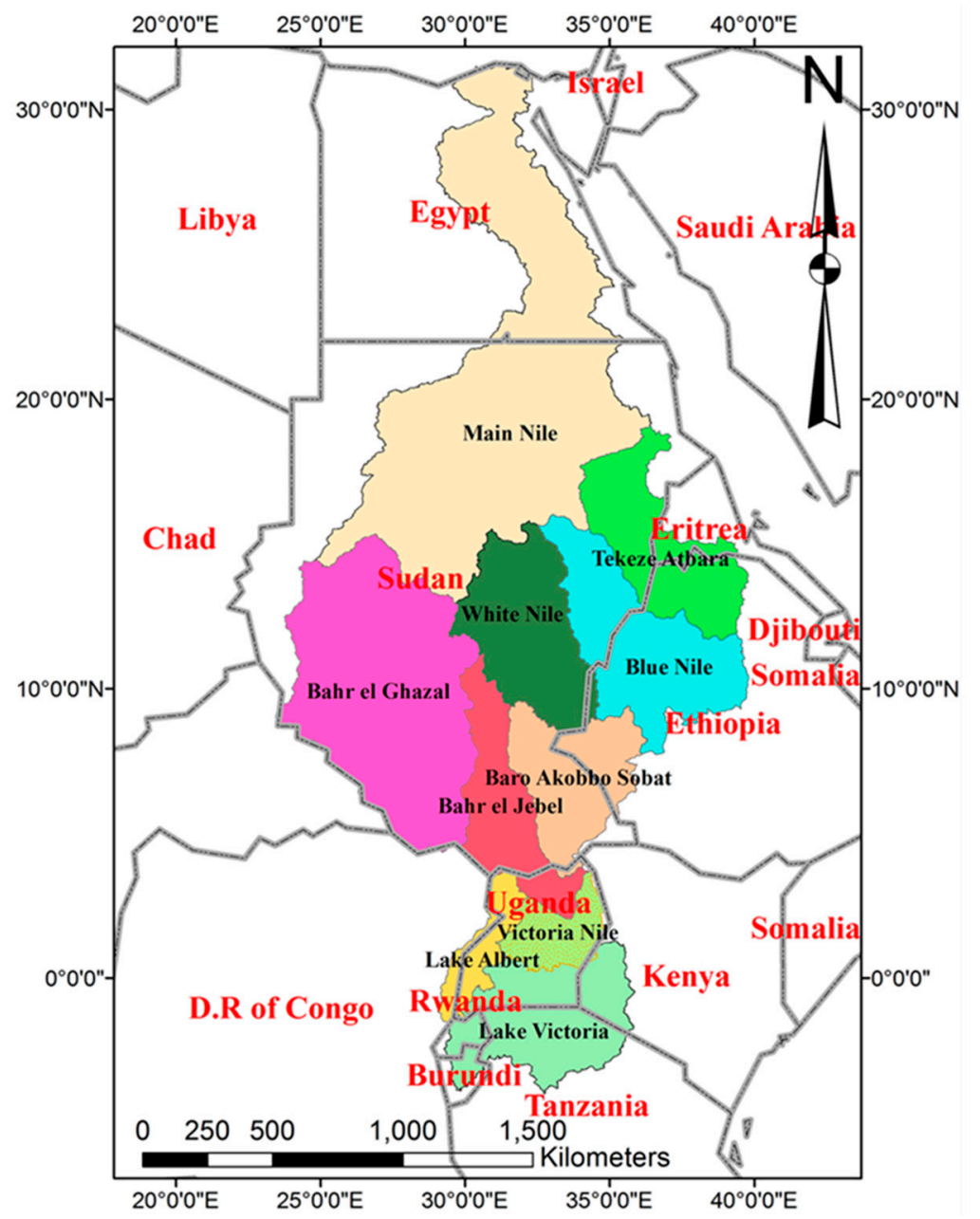

Figure 1. Location map of the Nile River Basin recognized by Nile Basin Initiative (2016). 


\subsection{The InVEST Annual Water Yield Model}

The InVEST annual water yield model is a biophysical water balance model that computes water production capacity for the different parts of the watershed or sub-watershed. The Natural Capita Project developed this model to quantify water production of a landscape, and it is under development [18]. We used version 3.3.3 of InVEST water simulation to simulate annual mean water production of the Nile River Basin. It calculates water production at a pixel level to capture the heterogeneity of the landscape but reported at a watershed or sub-watershed level. The InVEST annual water yield is selected for this study because of its applicability in data scarce areas such as the Nile Basin. The model is designed to accept globally available data and its structure is limited to key biophysical processes involved in land-use change. This study could be regarded as the first to test the practical applicability of InVEST water yield model based on remote sensing data for water yield estimation in the Nile River Basin. Therefore, our study will pave the way for non-technical people to evaluate the impact of land use change on water production capacity of the ecosystem at the local scale in the study area by avoiding the problem of observed data paucity. The InVEST Annual water yield model used a simple assumption compared with other water balance models. It assumes water production $(y)$ for each pixel $(x)$ of the landscape as annual precipitation $(p)$ minus annul evapotranspiration (AET) (Equation (1)):

$$
y(x)=\left(1-\frac{\operatorname{AET}(x)}{p(x)}\right) \times p(x) .
$$

Catchment level actual evapotranspiration measurement is practically highly problematic. To overcome this problem, the InVEST associates AET to potential evapotranspiration (PET) following Zhang et al. [20] (Equation (2)):

$$
\frac{\operatorname{AET}(x)}{P(x)}=1+\frac{\operatorname{PET}(x)}{P(x)}-\left[1+\left(\frac{\operatorname{PET}(x)}{P(x)}\right)^{\omega}\right]^{1 / \omega} .
$$

PET can be easily calculated by multiplying reference evapotranspiration with crop coefficients of each pixel (Equation (3)):

$$
\operatorname{PET}(x)=K c(l x) \times \operatorname{ETo}(x) .
$$

Following Donohue et al. [21], $\omega(x)$ is defined as follows because $\omega$ is characterized by precipitation, plant available water content (AWC) and seasonality factor $(Z)$, which elucidate local hydrological properties including precipitation pattern (Equation (4)):

$$
\omega(x)=Z \frac{\operatorname{AWC}(x)}{P(x)}+1.25 .
$$

The minimum value of $\omega(x)$ is 1.25 at which the ground is bare. According to Donohue et al. [21] and Yang et al. [22], the average values of $\omega(x)$ are approximately five.

\subsection{Model Input Variables and Preparation}

The InVEST annual water yield model required nine tabular and biophysical parameters. These are climate and environment related for example precipitation, evapotranspiration, root restricting layer depth, plant available water content, watershed, sub-watersheds, land use and land cover, biophysical table and $Z$ parameter.

The most essential input data for water balance modeling is precipitation. In our study, openly accessible precipitation product from WorldClim version 1.4 was applied. It is average monthly precipitation for 12 months from 1960-1990 with a spatial resolution of about $1 \mathrm{~km}^{2}$ [23]. The second largest water balance modeling input data is ETo. The Consultative Group on International Agricultural Research, Consortium on Spatial Information (CGIAR-CSI) dataset was the source of an average annual 
ETo for this study. We obtained data for the period 1950-2000 with $1 \mathrm{~km}^{2}$ spatial resolution, which is in the range of the precipitation data temporal resolution [24]. We used Harmonized World Soil Database version 1.2 to generate root restricting layer depth and Plant Available Water Content for this study. Root restricting layer depth is not available in the study area; reference soil depth was used as a proxy [25]. Land Use and Land Cover (LULC) datasets of the study area for 1981-1994 with $1 \mathrm{~km}^{2}$ spatial resolution was provided by the University of Maryland [26]. Watershed and sub-watersheds of the study area was obtained from NBI on request, which was delineated in 2016.

Zhang constant ( $Z$ parameter) is an empirical constant that characterizes the seasonality of precipitation, and additional hydrogeological properties within possible ranges of values between 1 to 30. Calibration, using local $\omega$ values and using the annual number of rain events, are the three options to calculate $Z$ parameter proposed by the InVEST user's guide [18]. For our study, we used local $\omega$ values and $Z=(\omega-1.25) \times(P / A W C)$. In addition to the aforementioned biophysical parameters, the model also needs tabular data of each LULC type like root depth, plant evapotranspiration coefficient and cover type of the land. We estimated root depth following Canadell et al. [27] and evapotranspiration coefficient based on Allen et al. [28] and the InVEST user guide [18]. Tables A1 and A2 in the Appendix A present a summary of input parameters used for this study.

\section{Results}

\subsection{Model Calibration and Result Validation}

Model calibration and validation are necessary and should be performed using long-term average streamflow [18]. Unlike the development of any complex or process-based hydrological model where calibration and validations of model is challenging and a certain degree subjective, model calibration and validation for InVEST is simple and objective. We delineated sub-watershed above Diem stream gauge where observations are measured with the InVEST RouteDEM program and created a shapefile of Upper Blue Nile sub-watershed. Then, we run the simulation for the Upper Blue Nile sub-watershed and compared model results with the observed data obtained from NBI and Ministry of Water and Energy, Ethiopia.

We used Diem station hydrological records from 1914 to1964 for model calibration and from 1965 to 2014 for result validation. The Diem station was purposefully selected because the flow at this station can be considered approximately natural flow conditions due to limited man-made interventions, and contributes to about $70 \%$ of the combined flows of all Nile tributaries [19]. Therefore, calibrating the model and validating the result with Diem station record is ideal. The initial model result was compared with measured flow data. Then, we adjusted plant evapotranspiration coefficients and root depth for each LULC class based on available data and literature. After we fine-tuned plant evapotranspiration coefficients and root depth for each LULC class manually, hydrological simulation for the Upper Blue Nile sub-watershed was carried out. We applied the pairwise comparison statistics techniques like Bias, Root Mean Square Error (RMSE) and Mean Error (ME) for evaluation of model estimates of annual water yield. The ME and RMSE values of the calibration results were $-0.02 \mathrm{~km}^{3} /$ year and $0.02 \mathrm{~km}^{3}$ /year, respectively, which are near the perfect score zero. In addition, the Bias value of the final calibration result was 0.99 , which is near the ideal value of Bias (1.00). Finally, hydrological simulation for the entire Nile Basin was carried out. The final model result was compared with measured flow data for Upper Blue Nile sub-watershed using Zonal Statistics (Figure 2). The ME and RMSE value of the final model results were $-0.03 \mathrm{~km}^{3} /$ year and $0.03 \mathrm{~km}^{3} /$ year, respectively, which are near the perfect score zero. In addition, the Bias value of the final model result was 0.99 , which is near the ideal value of Bias (1.00). The aforementioned parameters determined through such validation were used for the model and results. 


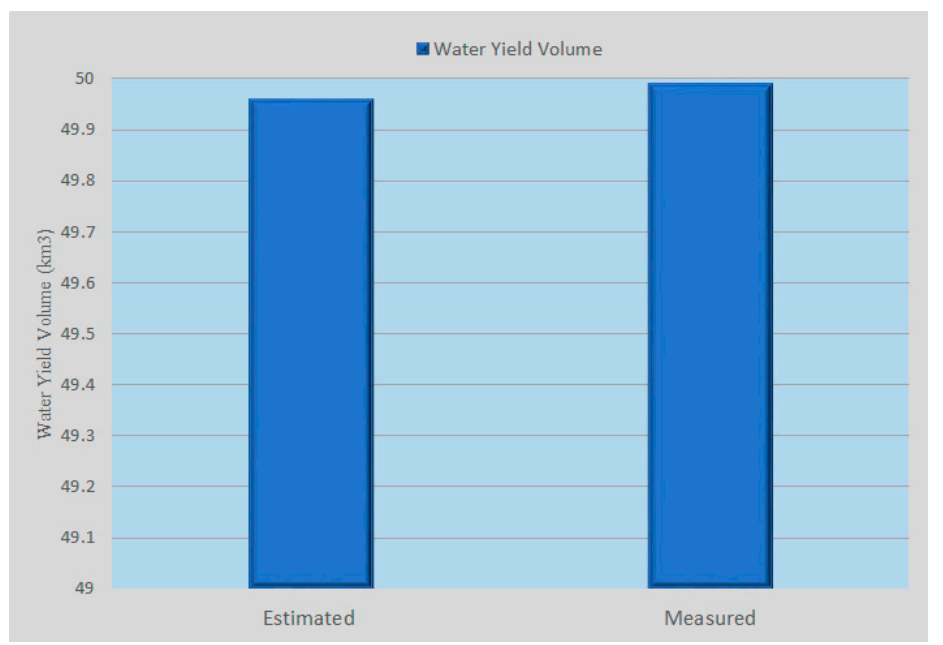

Figure 2. Comparison between the average annual estimated and measured water yield of Upper Blue Nile sub-watershed for the period 1960-1990.

\subsection{Mean Annual Precipitation}

The mean annual precipitation of WorldClim version 1.4 value between 1960-1990 is $596 \mathrm{~mm}$ /year $\left(2014 \mathrm{~km}^{3}\right)$ for the whole Nile Basin $\left(3,379,295 \mathrm{~km}^{2}\right)$. Kirby et al. [10] simulated rainfall volume of the whole Nile Basin using Climate Research Unit (CRU TS 2.10) data between 1901-2002. Their finding shows that the total volume of rainfall is $2043 \mathrm{~km}^{3} /$ year or $(627 \mathrm{~mm} /$ year), which is very close to the amount used in our study (deviation is $+5 \%$ ). Food and Agriculture Organization (FAO) conducted the irrigation potential of Nile Basin. The finding of FAO's study shows that the mean annual rainfall amount of the whole basin is $615 \mathrm{~mm}$, which is close to our study result (deviation is $+3 \%$ ) [29]. Bastiaanssen et al. [12] also computed Nile Basin water balance using Rainfall Estimates (RFE) data for the period 2006-2010. Their finding shows $600 \mathrm{~mm}$ is the average rainfall value of Nile River Basin, while our simulation shows that $596 \mathrm{~mm}$ is the average rainfall of the Nile. These results are comparable with Bastiaanssen et al. (deviation is $-0.6 \%$ ).

Figure 3 shows the mean annual precipitation of all 10 Nile sub-watersheds from the years 1960-1990. Lake Victoria, Victoria Nile, Lake Albert, Blue Nile and Baro-Akobo-sobat sub-watersheds generated high rainfall in the study area almost greater than $1000 \mathrm{~mm} /$ year. Therefore, Uganda, Ethiopia, Kenya and South Sudan received high precipitation in the Nile River Basin. Low precipitation totals $(46.61 \mathrm{~mm})$ were exhibited in Sudan and Egypt, the Main Nile sub-watershed. Hence, the northern part of the Nile Basin (Sudan and Egypt) are totally dependent on upstream watersheds rainfall surplus to access water.

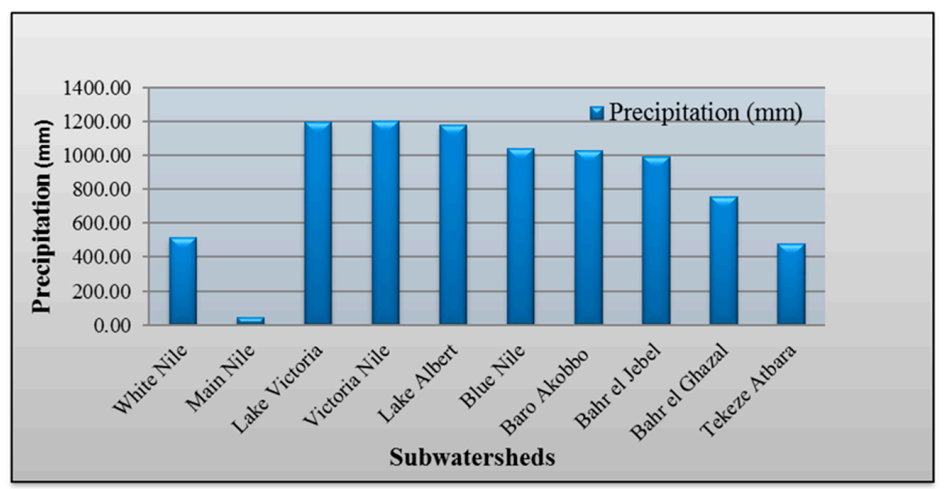

Figure 3. Mean annual precipitation of the Nile subwatersheds were estimated by using the WorldClim version 1.4 open-access rainfall product averaged for the period 1960-1990. 


\subsection{Actual Evapotranspiration}

While actual ET is the second largest hydrological flow path, the generation of open-access data sets for actual ET is in the infant stage and is not available online. Therefore, we used the InVEST model to estimate AET from Eto and Kc as a new model, and this was applied to the Nile River Basin.

Table 1 shows the estimated mean annual actual ET for all 10 Nile sub-watersheds. Lake Victoria ( $992.75 \mathrm{~mm} /$ year) is the sub-watershed with the maximum actual ET followed by Victoria Nile ( $969.8 \mathrm{~mm}$ /year) and Lake Albert $(910.78 \mathrm{~mm} /$ year), respectively. These sub-watersheds host extensive water bodies, forests and different biodiversity. In most of these areas, mean annual precipitation goes above $1150 \mathrm{~mm}$. The lowest actual ET by sub-watershed occurs in the Main Nile where most of the agro-ecology is bare ground and the agro-ecology is desert $(46.47 \mathrm{~mm} /$ year).

Table 1. Precipitation, actual evapotranspiration and water yield of Nile sub-watersheds.

\begin{tabular}{ccccc}
\hline Sub-Watersheds & Area $\mathbf{( k m}^{\mathbf{2}} \mathbf{)}$ & $\begin{array}{c}\text { Precipitation } \\
\mathbf{m m} \text { /year }\end{array}$ & AET $\mathbf{m m}$ /year & $\begin{array}{c}\text { Water Yield Volume Billion } \\
\mathbf{m}^{\mathbf{3}} \text { /year }\end{array}$ \\
\hline White Nile & 270,753 & 513 & 496 & 4.60 \\
Main Nile & $1,102,339$ & 47 & 46 & 0.04 \\
Lake Victoria & 264,083 & 1195 & 993 & 53.20 \\
Victoria Nile & 85,643 & 1200 & 970 & 19.62 \\
Lake Albert & 74,799 & 1180 & 911 & 19.89 \\
Blue Nile & 319,831 & 1041 & 781 & 82.86 \\
Baro Akobbo Sobat & 207,447 & 1025 & 863 & 33.50 \\
Bahr El Jebel & 187,610 & 990 & 848 & 26.55 \\
Bahr El Ghazal & 618,324 & 754 & 670 & 51.29 \\
Tekeze Atbara & 248,219 & 477 & 424 & 12.87 \\
\hline
\end{tabular}

Actual ET of the Nile Basin is estimated by Kirby et al. [10] as water use utilized by different ecosystems in the basin. The authors' findings show that the total volume of actual ET is $1828 \mathrm{~km}^{3} /$ year, being a difference of less than $7 \%$ compared with our results.

According to Bastiaanssen et al. [12] producing spatially distributed ET data for the Nile is a unique situation because ET data along with flow data could increase our understanding on water balance in a basin. In addition, distributed annual ET can be used to evaluate the response of the landscape based on its rainfall distribution. Figure 4 below shows average annual AET for the period 1950-2000 at $1 \mathrm{~km}^{2}$ spatial resolution.

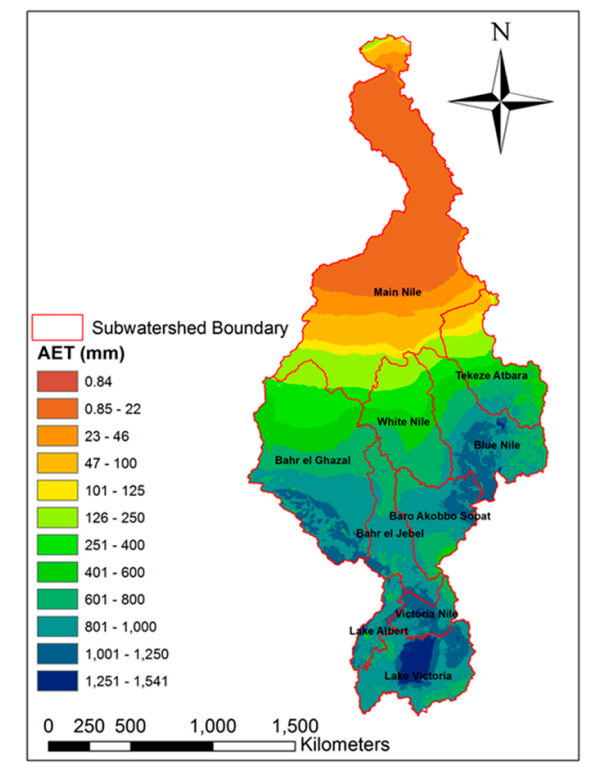

Figure 4. Spatially distributed average annual AET of the Nile basin for the period 1950-2000. 


\subsection{Water Balance}

InVEST annual water yield model assumes that all water in excess of evaporative loss is runoff or water yield. Figure 5 show the estimated annual runoff (Figure $5 a$ ), while Figure $5 b$ shows estimated actual evapotranspiration fraction of precipitation that actually evapotranspires. Lake Victoria, Victoria Nile, Lake Albert, Blue Nile and Baro-Akobo-sobat are sub-watersheds where maximum runoff generated and areas with low actual ET fraction in Figure $4 \mathrm{~b}$ show high runoff. The spatial distribution map of runoff volume produced in our simulation is in line with the findings of previous researchers $[9,11]$.

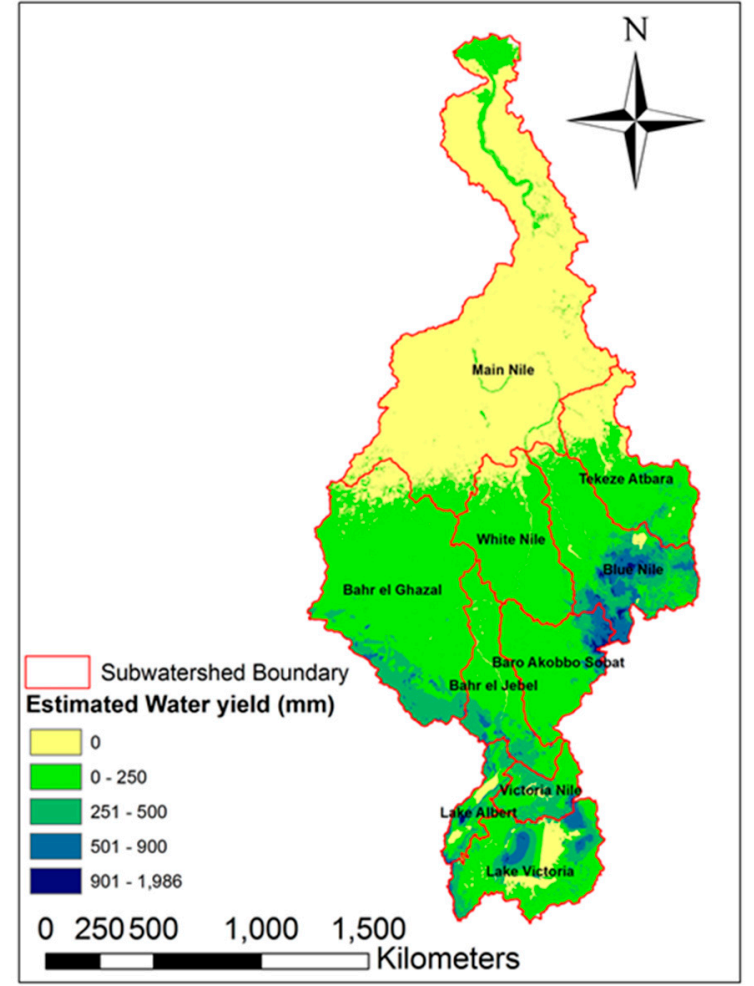

(a)

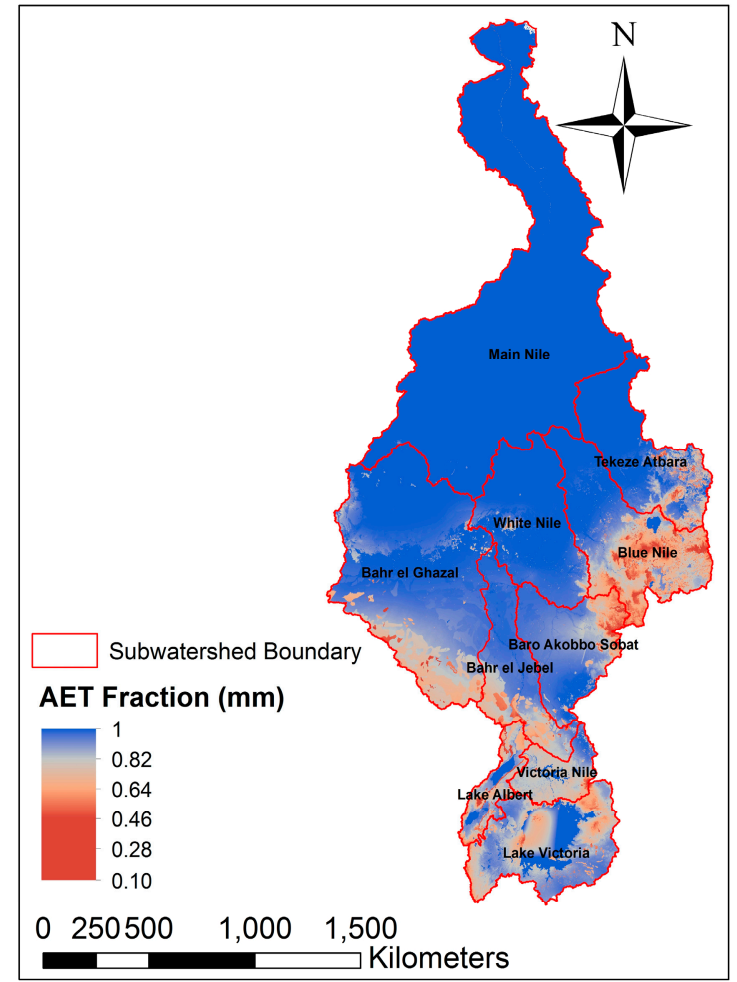

(b)

Figure 5. (a) estimated annual water yield ( $\mathrm{mm}) ;(\mathbf{b})$ estimated actual ET fraction.

The estimated water yield volume of each sub-watershed is presented in Figure 6. Annual average water yield is $304.51 \mathrm{~km}^{3}$, but water yield shows large spatial variation ranging from $0.04 \mathrm{~km}^{3}$ in Main Nile to $82.86 \mathrm{~km}^{3}$ in Blue Nile. The highest water yield is generated from Blue Nile, Lake Victoria and Bahr el Ghazal sub-watersheds at $82.9 \mathrm{~km}^{3}, 53.2 \mathrm{~km}^{3}$ and $51.3 \mathrm{~km}^{3}$, respectively. A considerable amount of water is also generated from sub-watersheds in the southern part of the Nile Basin, but contribution of sub-watersheds in the northern part of the basin is negligible.

Conway [30] produced an estimated water yield of $47.4 \mathrm{~km}^{3}$ between 1951 and 1987 for Abay Basin (Upper Blue Nile sub-watershed) utilizing a zone of $176,000 \mathrm{~km}^{2}$, which has similar temporal resolution to this study. Using the $176,000 \mathrm{~km}^{2}$ area utilized by Conway, $82.86 \mathrm{~km}^{3}$ stated in Table 1 is equivalent to $45.6 \mathrm{~km}^{3}$, which is similar to the findings of Conway. Bastiaanssen et al. [12] also reported an estimated water production of about $298 \mathrm{~km}^{3}$ for $3,229,039 \mathrm{~km}^{2}$ of the Nile Basin area between 2005 and 2010. Using the 3,229,039 km² area utilized by Bastiaanssen et al., $304.5 \mathrm{~km}^{3}$ stated earlier is equivalent to $291 \mathrm{~km}^{3}$, which is similar to the findings of Bastiaanssen et al. $(-2.42 \%)$. Despite the fact that the InVEST water yield model is very simple, the closeness (within 2.42\%) of the water production calculated for the Nile Basin shows the applicability of the model to estimate water balance components. 


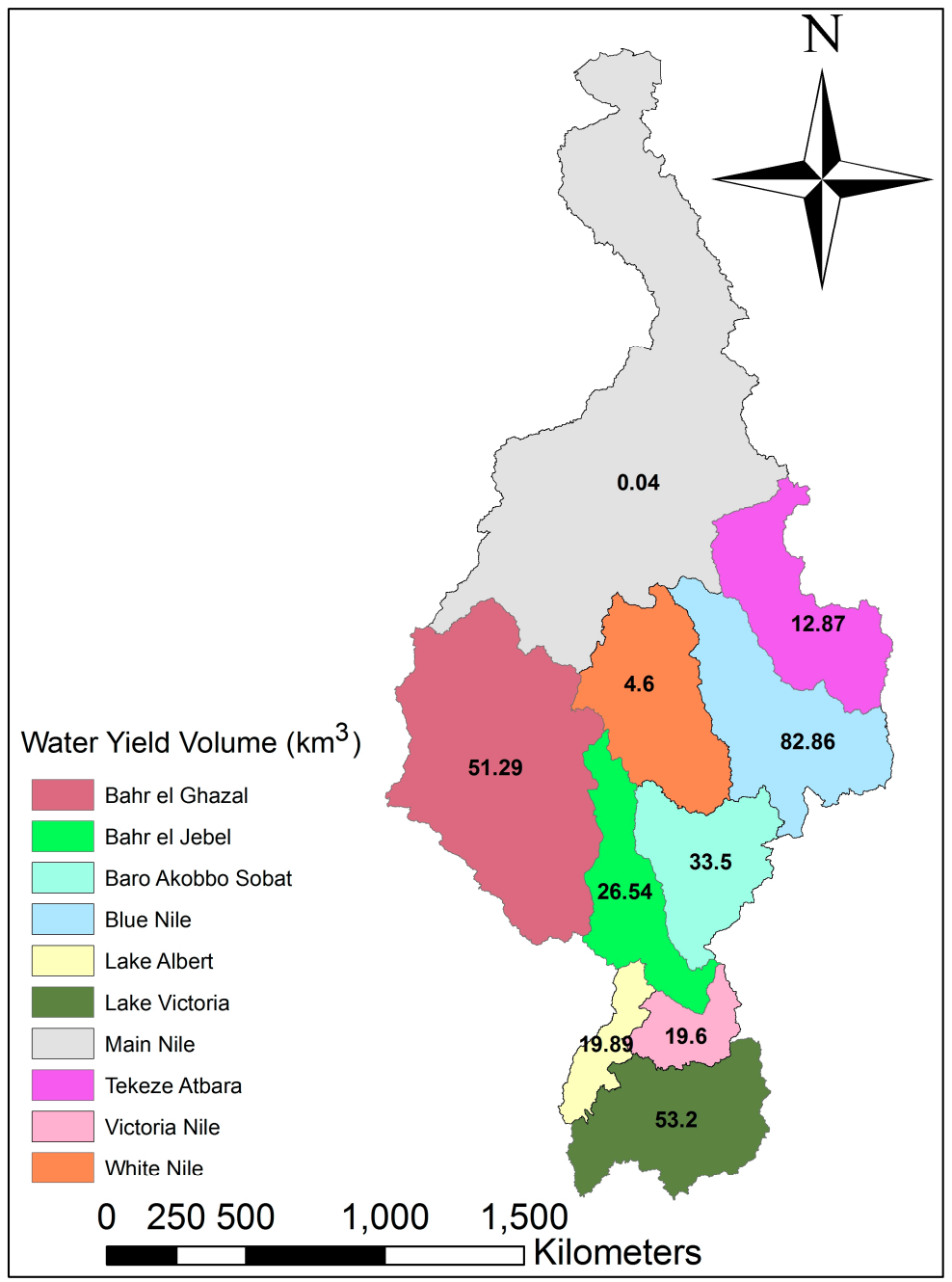

Figure 6. Annual average water yield volume estimated by sub-watershed in $\mathrm{km}^{3}$.

\section{Discussion}

\subsection{Major Water Balance Components of Nile River Basin}

In most African countries where the Nile River is situated, hydro-meteorological data are not available to the public domain. Therefore, application of complex hydrological models is difficult compared with simple hydrological models. In addition, the results of the simple hydrological model are far better than complex models due to data scarcity for model calibration and result validation for complex models $[8,10,13,15,17]$. Hence, the model introduced here is to predict water production, AET and precipitation of the Nile River Basin and its sub-basins system based on remotely sensed and globally available data with the simple model (InVEST).

Our finding shows that the InVEST water yield model can produce acceptable spatial distribution of water yield in different parts of the study basin. Therefore, the model accurately displays relative water yield contribution of each watershed in the study area (Figure 7). 


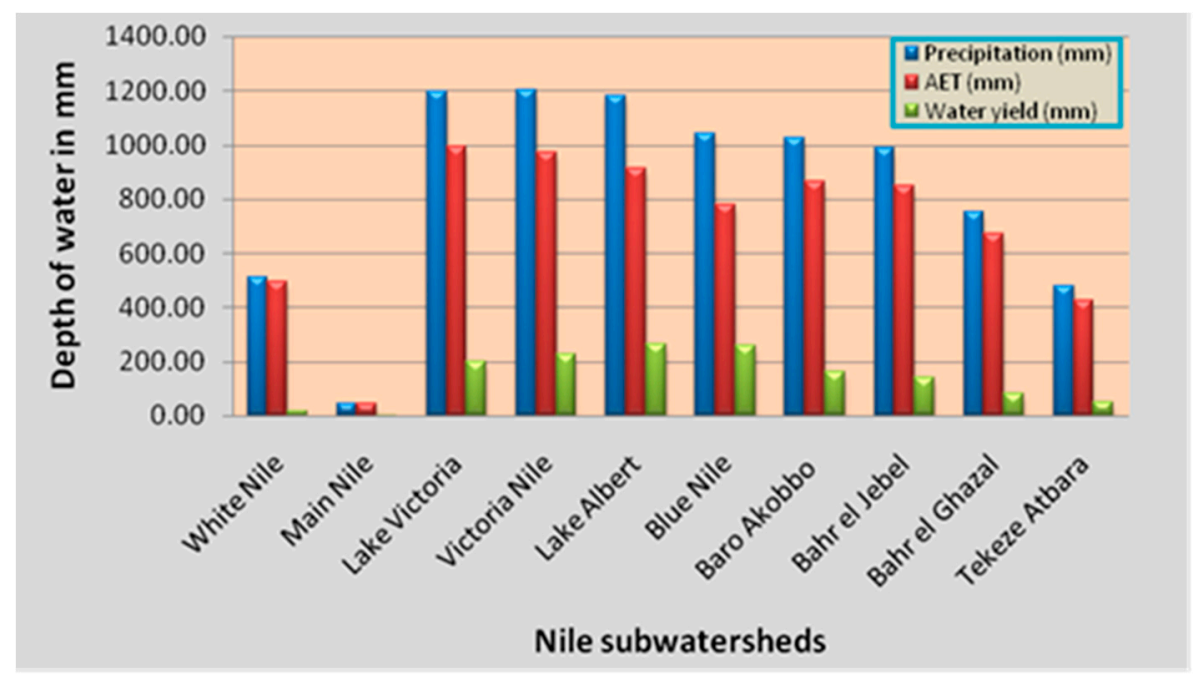

Figure 7. Estimated precipitation, AET and water yield of Nile sub-watersheds.

\subsection{Uncertainties in This Model}

Although the InVEST water yield model has good performance for estimating relative water production contribution of watersheds in the study area, model result accuracy is still dependent on empirical validation, which is difficult in scarce areas for observed data [31]. In addition, the InVEST water yield model has recognized limitations because water transfer, seasonal water production and partitioning between surface and ground water flow are not captured by the model [18].

Each open-access precipitation product has benefits and drawbacks, although providing organizations have firm data protocol and scientifically verified their products. Therefore, investigations are required to decide which data is appropriate for specific location, which is beyond the scope of this study [12,32-34]. This shows that certain uncertainty in the precipitation product exists. Another uncertainty in the model input data is the selection of $Z$ parameter. The robust way of selecting $Z$ parameter is calibration if there is enough observed data [35]. Since our study area is vast and has complex topography, it is hardly possible to calibrate $Z$ parameters. Therefore, this is a source of model structural uncertainty. However, we used one of the recommended ways of $Z$ parameter selection by Sharp et al. [18].

\subsection{Practical Implication}

Decision-makers and development planners require spatial and temporal information for different components of freshwater availability to make rational decisions and sustain ecosystem service provision for water. However, there is a lack of such information in the study area because of scarce input data for hydrological modeling in general and state-of-the-art models in particular. Hence, complex models demanding high input data and level of skill are difficult to use in the study area because hydrological data and model setup are not available in the public domain [12]. The aim of our research is to introduce the InVEST water yield model as it is user friendly, applies remotely sensed information, and model setup is easily accessible. Thus, non-technical people can use this model to evaluate the outcome of policy and development options implemented in different parts of the basin by downloading input data and model setup from the Internet.

This paper confirms that the ability of the InVEST water yield model to estimate annual spread of water yield production in the study area without flow meters. The model clearly shows the contribution of each landscape to the annual water production of the basin, which helps to prioritize which part of the basin will maximize water production ecosystem service if it is managed properly.

Bashar et al. [17] and Awulachew et al. [16] concluded that the accuracy of results from simple water balance models is better than more complex ones because of inadequate observed data for input, 
model calibration and result validation of complex models in the Nile River Basin. Mohamed et al. [8], Kirby et al. [10] and Bastiaanssen et al. [12] also suggested the use of remote sensing data in the Nile Basin to solve input data problems. Therefore, this study introduces a simple water balance model entirely dependent on open access and freely available data. We believed that the InVEST water yield model is capable of estimating water production contribution of different parts of the basin, although it has accepted limitations and simplifications. In order to evaluate this capability, future work should intend to compare the InVEST water yield model with process-based models.

\section{Conclusions}

Our work aimed to introduce the InVEST water yield model and demonstrate its applicability using the Nile River Basin to calculate and map the annual water yield. Annual water yield of the Nile Basin and its sub-watersheds were computed. The spatial distribution of annual water yield indicates a higher amount in the upstream, whereas the contribution of downstream portion is insignificant in the study area. The annual water yield volume of our result is very similar $(97.58 \%)$ with the result of state-of-the-art models published before in the study area. Furthermore, the spatial distribution map of the annual water yield is similar to runoff maps published by other researchers. Hence, the InVEST water yield model is capable of predicting water production patterns within large transboundary river basins such as the Nile without flow meters.

The introduction of simple water balance models has paramount importance for practical applications. Therefore, this model will help to evaluate the effects of implemented development strategies on water production capacity for different landscapes in the Nile River Basin. However, more research is recommended to assess model performance and compare with process-based models.

Acknowledgments: This research was funded by the National Science and Technology Support Projects (No. 2015BAC02B06), the Chinese Ministry of Environmental Protection (No. STSN-05-11) and Zhejiang Provincial Natural Science Foundation LY18G030006. The authors thank Editor Shirley Zhou and three anonymous reviewers for their constructive comments, suggestions and help in enhancing the manuscript.

Author Contributions: Marye Belete, Jinsong Deng and Mengmeng Zhou had the original idea for the study and all coauthors conceived and designed the methodology; Marye Belete and Mengmeng Zhou analyzed the data; Marye Belete wrote the paper, which was revised by Jinsong Deng and Melanie Weston; and all authors read and approved the final manuscript.

Conflicts of Interest: The authors declare no conflict of interest.

\section{Appendix A}

Table A1. Inputs data sources and statistics for water yield module (InVEST 3.3.3). Raster statistics are for the entire Nile river basin.

\begin{tabular}{ccccc}
\hline Input Data & Type or Format & Value (Mean and Range) & Spatial Resolution & Sources \\
\hline $\begin{array}{c}\text { Average annual } \\
\text { precipitation }(\mathrm{mm})\end{array}$ & GIS raster & $597(1-2296)$ & $1 \mathrm{~km} \times 1 \mathrm{~km}$ & WorldClim [23] \\
\hline $\begin{array}{c}\text { Average annual } \\
\text { ETo }(\mathrm{mm})\end{array}$ & GIS raster & $1970(746-2340)$ & $1 \mathrm{~km} \times 1 \mathrm{~km}$ & CGIAR CSI [36] \\
\hline Soil depth $(\mathrm{mm})$ & GIS raster & $835(100-1000)$ & $1 \mathrm{~km} \times 1 \mathrm{~km}$ & FAO, IIASA [37] \\
\hline PAWC $(\mathrm{mm})$ & GIS raster & $0.14(0-0.3)$ & $1 \mathrm{~km} \times 1 \mathrm{~km}$ & FAO, IIASA [37] \\
\hline LULC & GIS raster & see Table A2 & $1 \mathrm{~km} \times 1 \mathrm{~km}$ & $\begin{array}{c}\text { Global Land Cover } \\
\text { Facility (GLCF) [38] }\end{array}$ \\
\hline $\begin{array}{c}\text { Watershed and } \\
\text { Sub-watersheds }\end{array}$ & polygon/Shapefile & - & - & NBI [19] \\
\hline Root Depth & Per LULC class & see Table A2 & - & {$[27,28]$} \\
\hline Kc & Per LULC class & see Table A2 & - & {$[18,28]$} \\
\hline Z parameter & Integer number & $14.91(1-30)$ & - & {$[18]$} \\
\hline
\end{tabular}


Table A2. Biophysical table used for the InVEST model run, giving the root depth and $K c$ for each LULC class (values from $[18,26,27])$.

\begin{tabular}{ccccc}
\hline LULC Description & LULC Code & Kc & Root Depth & LULC_veg \\
\hline Water & 0 & 0.9 & 500 & 0 \\
Evergreen Broadleaf Forest & 2 & 1.05 & 7000 & 1 \\
Deciduous Broadleaf Forest & 4 & 1.05 & 7000 & 1 \\
Woodland & 6 & 0.85 & 3000 & 1 \\
Wooded Grassland & 7 & 0.85 & 5000 & 1 \\
Closed Shrub land & 8 & 0.35 & 3000 & 1 \\
Open Shrub land & 9 & 0.35 & 3000 & 1 \\
Grassland & 10 & 0.82 & 5000 & 1 \\
Cropland & 11 & 0.81 & 1000 & 1 \\
Bare Ground & 12 & 0.5 & 300 & 0 \\
Urban and Built & 14 & 0.37 & 500 & 0 \\
\hline
\end{tabular}

\section{References}

1. Haines-young, R.; Potschin, M. Chapter Six: The links between biodiversity, ecosystem services and human well-being. Ecosyst. Ecol. New Synth. 2010, 1-31. [CrossRef]

2. Pessacg, N.; Flaherty, S.; Brandizi, L.; Solman, S.; Pascual, M. Getting water right: A case study in water yield modelling based on precipitation data. Sci. Total Environ. 2015, 537, 225-234. [CrossRef] [PubMed]

3. Canqiang, Z.; Wenhua, L.; Biao, Z.; Moucheng, L. Water Yield of Xitiaoxi River Basin Based on InVEST Modeling. J. Resour. Ecol. 2012, 3, 50-54. [CrossRef]

4. Bastian, O.; Grunewald, K.; Syrbe, R.U. Space and time aspects of ecosystem services, using the example of the EU Water Framework Directive. Int. J. Biodiv. Sci. Ecosyst. Serv. Manag. 2012, 8, 5-16. [CrossRef]

5. Willcock, S.; Hooftman, D.; Sitas, N.; O’Farrell, P.; Hudson, M.D.; Reyers, B.; Eigenbrod, F.; Bullock, J.M. Do ecosystem service maps and models meet stakeholders' needs? A preliminary survey across sub-Saharan Africa. Ecosyst. Serv. 2016, 18, 110-117. [CrossRef]

6. Georgakakos, A.; Visone, L.; Tidwell, A. Nile Decision Support Tool. In Watershed Hydrology; The Georgia Water Resources Institute: Atlanta, GA, USA, 2003.

7. Levy, B.S.; Baecher, G.B. NileSim: A Windows-based hydrologic simulator of the Nile River basin. J. Water Resour. Plan. Manag. 1999, 125, 100-106. [CrossRef]

8. Mohamed, Y.A.; van den Hurk, B.J.J.M.; Savenije, H.H.G.; Bastiaanssen, W.G.M. Hydroclimatology of the Nile: results from a regional climate model. Hydrol. Earth Syst. Sci. Discuss. 2005, 9, 263-278. [CrossRef]

9. Senay, G.B.; Asante, K.; Artan, G. Water balance dynamics in the Nile Basin. Hydrol. Process. 2009, 3675-3681. [CrossRef]

10. Kirby, M.; Eastham, J.; Mainuddin, M. Water-Use Accounts in CPWF Basins: Simple Water-Use Accounting of the Nile Basin; The CGIAR Challenge Program on Water and Food: Colombo, Sri Lanka, 2010; Available online: https: / cgspace.cgiar.org/bitstream/handle/10568/4697/CPWF_BFP_WP_09.pdf?sequence=1 (accessed on 12 January 2017).

11. Senay, G.B.; Verdin, J.P. Developing index maps of water-harvest potential in Africa. Appl. Eng. Agric. 2004, 20, 789-799. [CrossRef]

12. Bastiaanssen, W.G.M.; Karimi, P.; Rebelo, L.; Duan, Z.; Senay, G.; Muthuwatte, L.; Smakhtin, V. Earth Observation Based Assessment of the Water Production and Water Consumption of Nile Basin Agro-Ecosystems. Remote Sens. Environ. 2014, 6, 10306-10334. [CrossRef]

13. Johnston, R.; Smakhtin, V. Hydrological Modeling of Large River Basins: How Much is Enough? Water Resour. Manag. 2014, 28, 2695-2730. [CrossRef]

14. Schuol, J.; Abbaspour, K.C.; Yang, H.; Srinivasan, R.; Zehnder, A.J.B. Modeling blue and green water availability in Africa. Water Resour. Res. 2008, 44, 1-18. [CrossRef]

15. Van Griensven, A.; Ndomba, P.; Yalew, S.; Kilonzo, F. Critical review of SWAT applications in the upper Nile basin countries. Hydrol. Earth Syst. Sci. 2012, 16, 3371-3381. [CrossRef] 
16. Awulachew, S.B.; McCartney, M.; Steenhuis, T.S.; Ahmed, A.A. A Review of Hydrology, Sediment and Water Resource Use in the Blue Nile Basin; IWMI Working Paper 131; The CGIAR Challenge Program on Water and Food: Colombo, Sri Lanka, 2008.

17. Bashar, K.E.; Mutua, F.; Mulungu, D.M.M.; Deksyos, T.; Shamseldin, A.Y. Appraisal study to select suitable Rainfall-Runoff model(s) for the Nile River Basin. In Proceedings of the International Conference of UNESCO Flanders FUST FRIEND/NILE Project, "Towards a Better Cooperation”, Sharm El-Sheikh, Egypt, 12-15 November 2005; Available online: https:/ / www.researchgate.net/publication/272826948_Appraisal_ Study_to_Select_Suitable_Rainfall-Runoff_Models_for_the_Nile_River_Basin (accessed on 19 May 2017).

18. Sharp, E.R.; Chaplin-Kramer, R.; Wood, S.; Guerry, A.; Tallis, H.; Ricketts, T.; Authors, C.; Nelson, E.; Ennaanay, D.; Wolny, S.; et al. InVEST 3.3.3 User's Guide. Available online: http:/ / data.naturalcapitalproject. org/nightly-build/release_default/release_default/documentation/index.html (accessed on 27 March 2017).

19. NBI. Nile Basin Water Resources Atlas. Available online: http://nileis.nilebasin.org/content/nile-basinwater-resources-atlas (accessed on 12 March 2017).

20. Zhang, L.; Hickel, K.; Dawes, W.R.; Chiew, F.H.S.; Western, A.W.; Briggs, P.R. A rational function approach for estimating mean annual evapotranspiration. Water Resour. Res. 2004, 40, W025021-W02502114. [CrossRef]

21. Donohue, R.J.; Roderick, M.L.; McVicar, T.R. Roots, storms and soil pores: Incorporating key ecohydrological processes into Budyko's hydrological model. J. Hydrol. 2012, 436-437, 35-50. [CrossRef]

22. Yang, H.; Yang, D.; Lei, Z.; Sun, F. New analytical derivation of the mean annual water-energy balance equation. Water Resour. Res. 2008, 44, 1-9. [CrossRef]

23. WorldClim 1.4: Current Conditions. Available online: http://www.worldclim.org/current (accessed on 17 January 2017).

24. Trabucco, A.; Zomer, R.J. Global Aridity Index (Global-Aridity) and Global Potential Evapo-Transpiration (Global-PET) Geospatial Database. CGIAR Consortium for Spatial Information. 2009. Available online: http: / / www.cgiar-csi.org/wp-content/uploads/2012/11/Global-Aridity-and-Global-PET-Methodology.pdf (accessed on 13 January 2017).

25. Fischer, G.; Nachtergaele, F.; Prieler, S.; van Velthuizen, H.T.; Verelst, L.; Wiberg, D. Global Agro-Ecological Zones Assessment for Agriculture (GAEZ 2008); FAO: Rome, Italy; IIASA: Laxenburg, Austria, 2012; pp. 1-50.

26. Hansen, M.C.; DeFries, R.S.; Townshend, J.R.; Sohlberg, R. Global land cover classification cation at $1 \mathrm{~km}$ spatial resolution using a classification tree approach. Int. J. Remote Sens. 2000, 21, 1331-1364. [CrossRef]

27. Canadell, J.; Jackson, R.; Ehleringer, J.; Mooney, H.A.; Sala, O.E.; Schulze, E.-D. Maximum rooting depth of vegetation types at the global scale. Oecologia 1996, 108, 583-595. [CrossRef] [PubMed]

28. Allen, R.G.; Pereira, L.S.; Raes, D.; Smith, M. Crop Evapotranspiration-Guidelines for Computing Crop Water Requirements; FAO Irrigation and Drainage Paper No. 56; FAO: Rome, Italy, 1998; Available online: http: / / www.fao.org/docrep/x0490e/x0490e00.htm (accessed on 28 December 2016).

29. FAO. Assessment of the Irrigation Potential of the Nile Basin; Land and Water Division, FAO: Rome, Italy, 1997; p. 41. Available online: http:/ /www.fao.org/docrep/W4347E/W4347E00.htm (accessed on 18 March 2017).

30. Conway, D. A water balance model of the Upper Blue Nile in Ethiopia. Hydrol. Sci. J./J. Des. Sci. Hydrol. 1997, 42, 265-286. [CrossRef]

31. Pan, T.; Wu, S.; Liu, Y. Relative contributions of land use and climate change to water supply variations over yellow river source area in Tibetan Plateau during the past three decades. PLoS ONE 2015, 10, e0123793. [CrossRef] [PubMed]

32. Dinku, T.; Ceccato, P.; Grover-Kopec, E.; Lemma, M.; Connor, S.J.; Ropelewski, C.F. Validation of satellite rainfall products over East Africa's complex topography. Int. J. Remote Sens. 2007, 28, 1503-1526. [CrossRef]

33. Duan, Z.; Liu, J.; Tuo, Y.; Chiogna, G.; Disse, M. Evaluation of eight high spatial resolution gridded precipitation products in Adige Basin (Italy) at multiple temporal and spatial scales. Sci. Total Environ. 2016, 573, 1536-1553. [CrossRef] [PubMed]

34. Redhead, J.W.; Stratford, C.; Sharps, K.; Jones, L.; Ziv, G.; Clarke, D.; Oliver, T.H.; Bullock, J.M. Empirical validation of the InVEST water yield ecosystem service model at a national scale. Sci. Total Environ. 2016, 569-570, 1418-1426. [CrossRef] [PubMed]

35. Hamel, P.; Guswa, A.J. Uncertainty analysis of a spatially explicit annual water-balance model: Case study of the Cape Fear basin, North Carolina. Hydrol. Earth Syst. Sci. 2015, 19, 839-853. [CrossRef] 
36. CGIAR. CSI-Consultative Group on International Agricultural Research, Consortium on Spatial Information. Available online: http:/ / csi.cgiar.org/Aridity/ (accessed on 17 January 2017).

37. FAO. IIASA - International Institute for Applied Systems Analysis (IIASA). Available online: http:/ / webarchive. iiasa.ac.at/Research/LUC/External-World-soil-database/HTML/ (accessed on 14 February 2017).

38. Global Land Cover Facility (GLCF). Available online: http://glcf.umd.edu/data/landcover/data.shtml (accessed on 17 February 2017). 